with older children acting as the leaders. After an excursion all gather together and the various records are taken and discussed. Any doubtful record is checked in the field. All records are then entered in a book to be held for future reference. During the school holidays other field work, such as counts of birds, counts of plants in a square, or series of squares, transects of areas, and similar studies are carried out. Certificates are awarded for individual field work, or individual study. 'Report forms' are also issued to all members to encourage them to record things they see. On these records the annual report is based. One evening a week during term-time a school classroom is hired and an indoor meeting arranged. This consists of a film or film-strip, or talk by experts on a variety of subjects ; the subjects are chosen by a committee of children. Outings to places of interest are also arranged. These include marshes, woodland areas, a heronry, a large winter roost for rooks and a winter roost for gulls. There is a small club library, from which the children may borrow books.

\section{Courses on Nuclear Energy in Europe}

A NEW edition of the "Catalogue of Courses on Nuclear Energy in O.E.E.C. Countries", covering the academic session 1958-59, has recently been issued by the European Nuclear Energy Agency of the O.E.E.C. (pp. 115. Paris : European Nuclear Energy Agency, Organization for European Economic Cooperation, 1958. 2, rue André-Pascal, Paris 16). It lists details of the courses on nuclear physics, nuclear engineering and related topics to be held in universities, technical colleges and research centres, together with practical information such as the names of the instructors or professors in charge, the durations of the courses, conditions of admission, fees, and the special pieces of equipment available. The information provided is not regarded as complete, but the catalogue should enable science and engineering students who wish to acquire a better knowledge of nuclear subjects to find out what training facilities exist and where and how to apply for them. The intending student is warned in the foreword that further information concerning any particular course should be obtained directly from the institution concerned, but it would have been perhaps wise to repeat this warning boldly throughout the catalogue, because in the case of the United Kingdom institutions, for example, the information given is neither well nor systematically chosen. To university authorities and others the catalogue will also be useful as a means of comparing the programmes of instruction in the educational establishments of the numerous countries listed and as a means of assessing the extent to which nuclear energy work has developed.

National Institute of Industrial Psychology Courses

THE National Institute of Industrial Psychology has issued details of courses and seminars arranged under its auspices during October 1958-May 1959. These include courses on personnel selection methods, held in three parts each of one week's duration, with two fourth parts, each of three days duration (open to those who have already attended the first three), on the selection of clerical personnel or, alternatively, of engineering apprentices. A course on the use of statistics in personnel management has been arranged jointly with the Institute of Personnel Management. A three-day course on staff reporting and merit-rating procedures, a five-day course in vocational guidance for youth employment officers and careers teachers, and two three-day seminars on psychological problems in inspection work and on personnel work in research organizations have also been arranged. Further particulars can be obtained from the Courses Secretary, National Institute of Industrial Psychologv, 14 Welbeck Street, London, W.1.

\section{Computer Symposia}

THE 1958 Computer Applications Symposium, organized by the Armour Research Foundation of the Illinois Institute of Technology, is to be held in Chicago on October 29 and 30. The purpose of the symposium will be to discuss computing and data processing devices from the point of view of users of such equipment. Business and management applications of computers will be stressed on the first day, engineering and scientific applications on the second day. Forms of application and further information can be obtained from M. J. Jans, Conference Secretary, Armour Research Foundation, 10 West 35th Street, Chicago 16, Illinois.

A Business Computer Symposium is to be held at Olympia, London, during December 1-3, in conjunction with the Electronic Computer Exhibition being held during November 28-December 4. An opening address is to be given by the Earl of Halsbury, managing director of the National Research Development Corporation, at whose instigation the Exhibition and Symposium have been organized jointly by the Electronic Engineering Association and the Office Appliance and Business Equipment Trades Association. The papers to be presented will cover practical experience of the use of computers for pay-rolls, production planning and management, file maintenance, public utility accounting, farm accounting, banking, insurance, stores control, research and design. Enrolment forms and further information can be obtained from the Electronic Computer Exhibition, 11/13 Dowgate Hill, London, E.C.4.

\section{Announcements}

Sir Alexander Fleck has been appointed chair man of the Scientific Advisory Council of the Ministry of Power, which was set up in 1948 to advise the Minister on the scientific aspects of his statutory duties. Its first chairman was Sir Alfred Egerton, followed in 1954 by Sir George Thomson.

THE Institute of Personnel Management is holding its 1958 National Conference during October 10-12 at Harrogate, on the theme "The Individual and the Organization in Modern Society". Further information can be obtained from Miss E. M. Harris, Institute of Personnel Management, 80 Fetter Lane, London, E.C.4.

A symposium on "The Tools of Biological Research" is to be held in the Physiology Theatre, Guy's Hospital, London, S.E.1, on October 10 and 11 , when the opening address will be delivered by Sir Cyril Hinshelwood. Further information can be obtained from Mr. H. J. B. Atkins, Department of Surgery, Guy's Hospital.

Erratum. In the article "Partition of Proteins in Liquid Polymer-Polymer Two-Phase Systems", by Dr. Per-Âke Albertsson, in Nature of September 13, p. 709, 'System $G$ ' should read 'System $C$ ' in : (1) Table 1 , column 3 ; (2) the legend to Fig. 2 ; (3) p. 710 , column 2, eighth line from the bottom. 